\title{
PENGARUH PENAMBAHAN pH BUFFER-EKSTRAK KUNYIT, EKSRAK DAUN ASAM DAN KOMBINASI EKSTRAK KUNYIT - DAUN ASAM (Curcuma domestica Val. - Tamarindus indicia L.) TERHADAP KARAKTERISTIK KRIM
}

\author{
I Kadek Alit Susendiana Adi, Sri Mulyani*, Bambang Admadi Harsojuwono \\ PS Teknologi Industri Pertanian, Fakultas Teknologi Pertanian, Universitas Udayana, Kampus Bukit \\ Jimbaran, Badung, Kode pos : 80361; Telp/Fax : (0361) 701801.
}

Diterima 15 Februari 2019 / Disetujui 13 Mei 2019

\begin{abstract}
This research aims to : 1) know the effect of $\mathrm{pH}$ buffer and active ingredients of turmeric extrac, tamarind leaves extract and combination turmeric-tamarind leaves extract on the characteristics of the cream produced. 2) determine the $\mathrm{pH}$ buffer and active ingredients of turmeric extrac, tamarind leaves extract and combination turmeric-tamarind leaves extract which produce the best cream characterstics. The study used factorial pattern randomized block design. The first factor is the addition of a buffer of the three levels, namely $\mathrm{pH}$ buffer 4, 5, 6. The second factor is the amount of turmeric exctrac, tamarind leaves extract, and mixied turmeric exctrac - tamarind leaves extract. The results of the study showed that the treatment of adding $\mathrm{pH}$ buffer had an effect on the $\mathrm{pH}$ of the cream, and did not affect the homogeneity of the cream, separation ratio, dispersion, viscosity, adhesion time, total phenolic. The addition of turmeric extract, tamarind leaves extract, and combination of turmeric-tamarind leaves extract had an effect on the $p H$ of the cream and total phenolic acid, whereas it did not affect homogeneity, separation ratio, spreadability, viscosity, adhesion time. All cream formulations meet SNI, namely homogeneity cream characteristics, separation ratio $=1, p H$, dispersion time, and total phenolic cream, with the best formulation at $\mathrm{pH} 4$ buffer and turmeric extract namely $\mathrm{pH}$ cream $(6,68)$, power spread of cream $(5,39) \mathrm{cm}$, cream viscosity $(20,200) \mathrm{cp}$, cream sticky time $(16.90)$ second, and total phenolic cream (10.83) $\mathrm{mg}$ GAE/g.
\end{abstract}

Keywords : cream, pH buffer, turmeric extrac, thamarin leaves exctrac, and combination turmericthamarin leaves extrac.

\section{ABSTRAK}

Penelitin ini bertujuan untuk : 1) mengetahui pengaruh $\mathrm{pH}$ buffer dan ekstrak kunyit, ekstrak daun asam dan kombinasi ekstrak kunyit-daun asam terhadap karakteristik krim yang dihasilkan. 2) menentukan pH buffer dan ekstrak kunyit, ekstrak daun asam dan kombinasi ekstrak kunyit-daun asam yang menghasilkan karakteristik krim terbaik. Penelitian ini menggunakan Rancangan Acak Kelompok pola faktorial. Faktor pertama yaitu penambahan buffer yang terdiri dari 3 taraf yaitu $\mathrm{pH}$ buffer 4 , pH buffer 5, pH buffer 6. Faktor kedua penambahan ekstrak kunyit, ekstrak daun asam dan kombinasi ekstrak kunyit - daun asam. Hasil penelitian menunjukkan perlakuan penambahan $\mathrm{pH}$ buffer berpengruh terhadap pH krim, dan tidak berpengaruh terhadap homogenitas, rasio pemisahan, daya sebar, viskositas,

*Korespondensi Penulis:

Email : srimulyani@unud.ac.id 
waktu lekat, total fenolik krim. Penambahan ekstrak kunyit, ekstrak daun asam, dan kombinasi ekstrak kunyit-daun asam berpengaruh terhadap $\mathrm{pH}$ krim dan total fenolik krim, sedangkan tidak berpengaruh terhadap homogenitas, rasio pemisahan, daya sebar, viskositas, waktu lekat krim. Larutan $\mathrm{pH}$ buffer mampu mempertahankan $\mathrm{pH}$ krim, penambahan daun asam mengakibatkan penurunan $\mathrm{pH}$ krim. Senyawa fenolik tertinggi dihasilkan pada penambahan ekstrak kunyit. Semua formulasi krim memenuhui SNI yaitu karakteristik krim homogen, rasio pemisahan =1, daya sebar, viskositas, waktu lekat, dan total fenolik, dengan formulasi terbaik pada $\mathrm{pH}$ Buffer 4 dan ekstrak kunyit yaitu $\mathrm{pH}$ krim $(6,68)$, daya sebar krim $(5,39) \mathrm{cm}$, viskositas $\operatorname{krim}(20,200) \mathrm{cp}$, waktu lekat krim $(16,90)$ detik, dan total fenolik krim $(10,83) \mathrm{mg}$ GAE/g.

Kata kunci : Krim, pH buffer, ekstrak kunyit, ekstrak daun asam, dan kombinasi ekstrak kunyit-daun asam.

\section{PENDAHULUAN}

Masyarakat modern saat ini semakin menyadari bahaya penggunaan bahan kimia yang berbahaya dalam kosmetik. Singh et al. (2011), menyatakan adanya kemungkinan reaksi negatif pada kulit karena campuran senyawa kimia yang berbahaya yang dapat menimbulkan alergi atau iritasi pada kulit. Krim merupakan bentuk sediaan setengah padat yang mengandung satu atau lebih bahan terlarut atau terdispersi dalam bahan dasar yang sesuai (Thamrin, 2012).

Kunyit merupakan salah satu bahan herbal yang mengandung zat antioksidan untuk menangkal radikal bebas karena adanya kandungan kurkumin (Purba dan Martosupono, 2009). Kurkumin sebagai senyawa fenolik berperan sebagai antioksidan, hal ini dikarenakan kandungan atom $\mathrm{H}$ pada senyawa fenolik sangat potensial sebagai antioksidan (Priyadarsini et al., 2003). Salah satu tanaman obat yang memiliki berbagai khasiat adalah asam jawa. Asam jawa bermanfaat untuk mengobati jerawat, serta mampu mengangkat sel kulit mati. Salah satu golongan kandungan aktif daun asam jawa adalah flavonoid yang memiliki efek antioksidan.. Antioksidan dapat melindungi sel-sel dari kerusakan yang diakibatkan oleh molekul tidak stabil yang dikenal sebagai radikal bebas (Yumas, 2016). Menurut penelitian Mulyani et al. (2006) menyatakan bahwa kunyit dan daun asam berpotensi sebagai sumber antioksidan.
Selanjutnya Mulyani dan Suhendra. (2010) juga melaporkan bahwa kunyit dan daun asam secara in vitro terbukti mempunyai aktifitas antioksidan dan campuran keduanya menunjukkan adanya sinergisme. Rasio (8:2) kunyit dan daun asam yang mempunyai sinergisme antioksidan tertinggi sebesar 113,894 persen (Mulyani, 2017).

Penelitian tentang krim ekstrak kunyit sudah dilakukan, namun masih terdapat kelemahan yaitu $\mathrm{pH}$ krim yang belum memenuhi standar (Natalie et al, 2017). Larutan buffer (penyangga) adalah larutan yang digunakan untuk mempertahankan $\mathrm{pH}$ (Herawati, 2008). Perlu dilakukan penelitian lebih lanjut tentang pengaruh $\mathrm{pH}$ buffer dan jenis bahan aktif agar diperoleh krim dengan aktifitas antioksidan terbaik dan $\mathrm{pH}$ memenuhi standar. Tujuan penelitian ini adalah mengetahui pengaruh $\mathrm{pH}$ buffer, ekstrak kunyit, ekstrak daun asam, dan kombinasi ekstrak kunyit-daun asam. Tujuan penelitian yang lain adalah $\mathrm{pH}$ buffer, ekstrak kunyit, ekstrak daun asam, dan kombinasi ekstrak kunyit-daun asam yang menghasilkan karakteristik krim terbaik.

\section{METODE PENELITIAN}

\section{Tempat dan Waktu Penelitian}

Penelitian ini dilaksanakan di Laboratorium Biokimia dan Nutrisi, Laboratorium Analisis Pangan Fakultas Teknologi Pertanian, Universitas Udayana. Waktu pelaksanaan penelitian dimulai dari 
Agustus sampai Oktober 2018.

\section{Bahan dan Alat Penelitian}

Bahan yang digunakan adalah ekstrak kunyit (Banjar Batu Lantang, Petang, Badung yang berumur kurang lebih 11 bulan), ekstrak daun asam (Banjar Balangan, Mengwi, Badung, diambil 3 daun dihitung dari pucuk daun), etanol 96\% (Brataco), asam stearat (Emsure), $\mathrm{pH}$ buffer sitrat, virgin coconut oil (VCO) (Bali coconut), mineral oil (Emsure), trietanolamin (Emsure), setil alcohol (Merck), aquades (Waterone), moinsture conditioner (propilen glikol (Emsure), sorbitot (Emsure), gliserol (Emsure).

Peralatan yang digunakan dalam penelitian ini adalah neraca analitik (Sortorius), rotari evaporator (IKA HB 10), viskometer (Brookfield), spektrofotometer (Biocrom Libra SN 133467), pH meter (Hanna), water bath (Selecta Precisdig), centrifuge (Hettich Rotofix 32), pipet mikro, labu erlenmeyer (Iwaki), kertas saring (Whatman), gelas ukur (Iwaki), cawan petri (Iwaki), lempeng gelas (Iwaki), tabung reaksi (Iwaki), Kuvet (Plastibrand), corong (Herma), batang pengaduk (Herma), tabung centrifuge (Nesco).

\section{Rancangan Penelitian}

Penelitian ini menggunakan rancangan acak kelompok (RAK) pola faktorial dengan dua faktor, faktor pertama yaitu penambahan buffer, dan yang kedua penambahan bahan aktif dalam emulsi krim. Presentase penambahan buffer terdiri dari 3 taraf yaitu : B1: $\mathrm{pH} 4, \mathrm{~B} 2: \mathrm{pH} 5, \mathrm{~B} 3: \mathrm{pH}$ 6. Presentase penambahan bahan aktif terdiri dari 3 taraf yaitu: P1 : ekstrak kunyit, P2 : ektrak daun asam, P3 : ekstrak kunyit-daun asam rasio (8:2). Dari kombinasi perlakuan tersebut diperoleh 9 unit percobaan. Perlakuan dikelompokkan berdasarkan waktu pelaksanaan menjadi 2 sehingga diperoleh 18 unit percobaan. Data obyektif dianalisis dengan menghitung nilai rata-rata dan disajikan dalam bentuk tabel dan grafik serta menggunakan statistik parametrik berupa analisis varian (Anova) dan apabila perlakuan berpengaruh akan dilanjutkan dengan uji Duncan.

\section{Pelaksanaan Penelitian}

Pembuatan krim dilakukan dengan tiga tahapan yaitu : persiapan $\mathrm{pH}$ buffer, persiapan ekstrak, pembuatan basis krim, dan analisis krim.

Persiapan ekstrak kunyit : rimpang kunyit, dicuci, kemudian ditiriskan. Selanjutnya kunyit diiris dengan ketebalan $\pm 0,1 \mathrm{~cm}$, lalu dikeringkan dengan oven pada suhu $55^{\circ} \mathrm{C}\left( \pm 2^{\circ} \mathrm{C}\right)$ sampai mencapai kadar air maksimal 10\%. Simplisia kunyit dibuat menjadi bubuk dengan ukuran 60 mesh . Selanjutnya 200 gram bubuk kunyit diekstrak dengan pelarut etanol $96 \%$ secara maserasi dengan rasio bahan : pelarut ( $1: 6)$. Maserasi tahap pertama dilakukan selama 24 jam dengan dua kali pengadukan. Selanjutnya setelah 24 jam dilakukan penyaringan menggunakan kertas whatman no.1, penyaringan dilakukan untuk memisahkan antara ampas dengan filtrat. Ampas sisa penyaringan dilakukukan maserasi kembali. Setelah proses remaserasi, filtrat yang didapat diuapkan menggunakan evaporator. Hasil penguapan yang diperoleh merupakan ekstrak kunyit.

Persiapan ekstrak daun asam : pisahkan daun asam dari batang keras, selanjutnya daun asam dikeringkan dengan oven pada suhu $55^{\circ} \mathrm{C} \quad\left( \pm 5^{\circ} \mathrm{C}\right)$ sampai mencapai kadar air maksimal $10 \%$. Simplisia daun asam dibuat menjadi bubuk dengan ukuran 60 mesh. Selanjutnya 200 gram bubuk daun asam diekstrak dengan pelarut etanol 96\% secara maserasi dengan rasio bahan : pelarut (1 : 6). Maserasi tahap pertama dilakukan selama 24 jam dengan dua kali pengadukan. Selanjutnya setelah 24 jam dilakukan penyaringan menggunakan kertas 
whatman no.1, penyaringan dilakukan untuk memisahkan antara ampas dengan filtrat. Ampas sisa penyaringan dilakukukan maserasi kembali. Setelah proses remaserasi, filtrat yang didapat diuapkan menggunakan evaporator. Hasil penguapan yang diperoleh merupakan ekstrak daun asam. Formula krim yang digunakan dalam penelitian ini seperti yang ditunjukan pada Tabel 1.

Tabel 1. Formula krim yang digunakan dalam penelitian (modifikasi Natalie, 2017)

\begin{tabular}{|c|c|c|c|c|c|c|c|c|c|c|}
\hline \multirow{2}{*}{ No } & \multirow{2}{*}{ Jenis bahan } & \multicolumn{9}{|c|}{ Persentase formula } \\
\hline & & \multicolumn{3}{|c|}{ Kunyit } & \multicolumn{3}{|c|}{ Daun asam } & \multicolumn{3}{|c|}{ Kunyit + daun asam } \\
\hline 1 & Ekstrak (g) & 0,15 & 0,15 & 0,15 & 0,15 & 0,15 & 0,15 & 0,15 & 0,15 & 0,15 \\
\hline 2 & Buffer $(\mathrm{g})$ & 1.5 & 1.5 & 1.5 & 1.5 & 1.5 & 1.5 & 1.5 & 1.5 & 1.5 \\
\hline 3 & Asam stearat (g) & 10,91 & 10,91 & 10,91 & 10,91 & 10,91 & 10,91 & 10,91 & 10,91 & 10,91 \\
\hline 4 & VCO (g) & 3,64 & 3,64 & 3,64 & 3,64 & 3,64 & 3,64 & 3,64 & 3,64 & 3,64 \\
\hline 5 & Mineral oil (g) & 2,27 & 2,27 & 2,27 & 2,27 & 2,27 & 2,27 & 2,27 & 2,27 & 2,27 \\
\hline 6 & $\begin{array}{l}\text { Moisturizer } \\
\text { conditioner (g) }\end{array}$ & 10,91 & 10,91 & 10,91 & 10,91 & 10,91 & 10,91 & 10,91 & 10,91 & 10,91 \\
\hline 7 & Setil alkohol (g) & 0,91 & 0,91 & 0,91 & 0,91 & 0,91 & 0,91 & 0,91 & 0,91 & 0,91 \\
\hline 8 & Ttrietanolamin & 0,5 & 0,5 & 0,5 & 0,5 & 0,5 & 0,5 & 0,5 & 0,5 & 0,5 \\
\hline 8 & $\begin{array}{l}\text { Penambahan air } \\
\text { sampai }(\mathrm{g})\end{array}$ & 100 & 100 & 100 & 100 & 100 & 100 & 100 & 100 & 100 \\
\hline
\end{tabular}

Pembuatan sediaan krim terdapat dua fase, yaitu fase air dan fase minyak. Fase minyak terdiri dari asam stearate, virgin coconut oil (VCO), mineral oil, setil alkohol. Fase air yaitu water (aquades), buffer, moisture conditioner, trietanolamin. Fase minyak dan air dipanaskan pada suhu $65^{\circ} \mathrm{C}$.

\section{HASIL DAN PEMBAHASAN}

\section{Homogenitas krim}

Berdasarkan hasil uji homogenitas menunjukkan bahwa seluruh sediaan krim tercampur secara merata. Krim homogen ditandai dengan penyebaran warna dan pencampuran sediaan krim tetap merata serta tidak adanya butiran-butiran kasar. Menurut Kurniasih, (2016) penambahan emulsifier berupa setil alkohol dan trietanolamin bermanfaat untuk menstabilkan emulsi. Suatu sediaan krim harus homogen dan terdistribusi merata agar tidak menyebabkan iritasi ketika dioleskan pada permukaan kulit. Hal tersebut sesuai dengan persyaratan sediaan krim harus menunjukkan susunan yang homogen dan tidak terlihatnya butiran - butiran kasar (Lubis, 2012).

\section{Rasio pemisahan krim}

Hasil penelitian dari rasio pemisahan krim diperoleh bahwa seluruh krim tidak terjadi pemisahan emulsi dari minggu ke- 0 hingga minggu ke- 6 , dan memiliki nilai rasio pemisahan $=1$. Emulsi krim dikatakan stabil jika nilai rasio pemisahan $=1$ yang artinya bahwa emulsi tidak memisah. Pengujian ini ditentukan dengan cara mengamati perbandingan antara tinggi fase krim yang memisah dengan tinggi emulsi mula-mula dengan menggunakan metode sentrifugasi. Tidak terjadinya pemisahan krim diduga karena penggunaan kombinasi emulsifier asam stearat dan trietanolamin yang menyebabkan emulsi menjadi stabil. Kemampuan emulsifier gabungan untuk mengikat lebih kuat molekul-molekul zat aktif permukaan menambah kekuatan lapisan antar muka, dan karenanya menambah kestabilan emulsi. Emulsifier bekerja dengan membentuk lapisan disekeliling tetesan terdispersi sehingga mencegah terjadinya pemisahan cairan terdispersi (Anief, 2008).

\section{Derajat keasaman krim (pH)}

Hasil analisis keragaman pada minggu 
ke-6 menunjukkan bahwa perlakuan $\mathrm{pH}$ buffer dan penambahan ekstrak berpengaruh sangat nyata $(\mathrm{P}<0,01)$, interaksi perlakuan $\mathrm{pH}$ buffer dan penambahan ekstrak tidak berpengaruh nyata $(\mathrm{P}>0,05)$. Nilai rata-rata $\mathrm{pH}$ krim ekstrak kunyit, daun asam, dan kunyit-daun asam pada minggu ke-6 dapat dilihat pada Tabel 2.

Tabel 2. Nilai rata-rata $\mathrm{pH}$ krim ekstrak kunyit, daun asam, dan kunyit-daun asam pada minggu ke6.

\begin{tabular}{lcccc}
\hline \multirow{2}{*}{ Ekstrak } & \multicolumn{3}{c}{$\mathrm{pH}$ buffer } & \multirow{2}{*}{ Rata-rata } \\
\cline { 2 - 4 } & $(\mathrm{B} 1) 4$ & $(\mathrm{~B} 2) 5$ & $(\mathrm{~B} 3) 6$ & \\
\hline (P1) ekstrak kunyit & 6,68 & 6,70 & 6,71 & $6,69 \mathrm{a}$ \\
(P2) ektrak daun asam & 6,56 & 6,57 & 6,61 & $6,58 \mathrm{c}$ \\
(P3) ekstrak kunyit-daun asam & 6,63 & 6,65 & 6,66 & $6,65 \mathrm{~b}$ \\
\hline Rata-rata & $6,62 \mathrm{a}$ & $6,64 \mathrm{~b}$ & $6,66 \mathrm{c}$ & \\
\hline
\end{tabular}

Keterangan : huruf yang sama di belakang nilai rata rata menunjukkan perbedaan yang tidak nyata $(\mathrm{P}>0,05)$.

Tabel 2. menunjukkan $\mathrm{pH}$ krim pada minggu ke-6 tertinggi didapat dari penambahan ekstrak kunyit pada perlakuan pH buffer 6 yaitu $(6,66)$. pH rendah di dapat dari penambahan ekstrak daun asam pada perlakuan $\mathrm{pH}$ buffer 4 yaitu $(6,62)$. Penambahan $\mathrm{pH}$ buffer pada sediaan krim bertujuan untuk mempertahankan $\mathrm{pH}$. Selain senyawa asam yang terdapat pada bahan aktif, emulsifier berupa asam stearat juga berpegaruh terhadap $\mathrm{pH}$ krim di karenakan gugus asam yang terkandung dalam asam stearat (Kurniasih, 2016).

Gambar 1. Grafik pH krim selama 6 minggu penyimpanan.

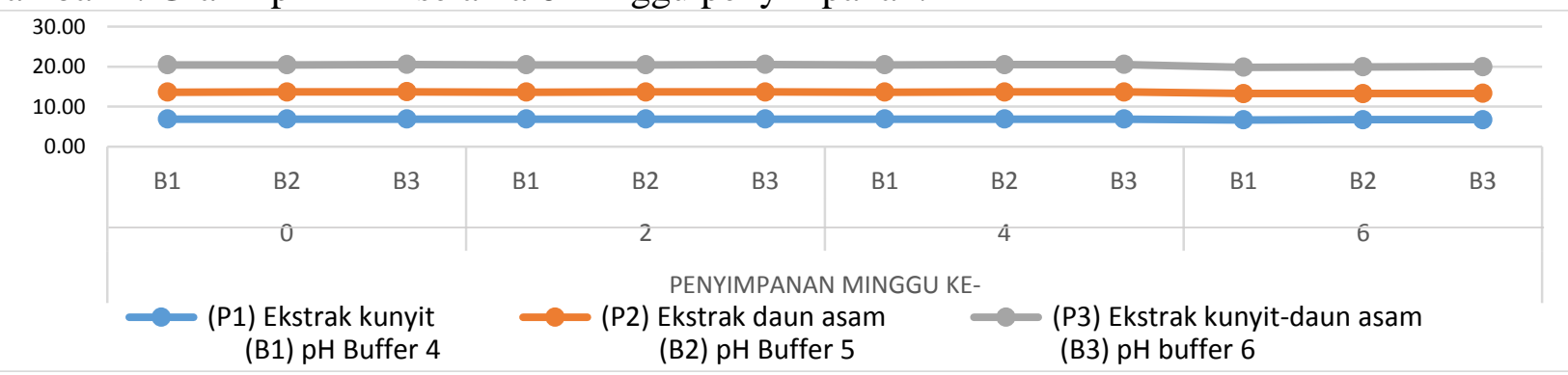

Hasil ini menunjukkan $\mathrm{pH}$ krim selama penyimpanann minggu ke-6 masih stabil (Gambar 1). Menurut Tranggono dan Latifah, (2007) $\mathrm{pH}$ krim yang baik berkisar antara $\mathrm{pH}$ 4,5-6,5. Hasil pengamatan menunjukkan $\mathrm{pH}$ sediaan krim selama penyimpanan minggu ke-0 sampai minggu ke- 6 berada pada kisaran pH 6,56-6,88.

\section{Daya sebar krim}

Berdasarkan hasil analisis keragaman pada minggu ke-6 menunjukkan bahwa perlakuan $\mathrm{pH}$ buffer dan penambahan ekstrak tidak berpengaruh nyata $(\mathrm{P}>0,05)$ terhadap daya sebar krim. Nilai rata-rata daya sebar krim ekstrak kunyit, daun asam, dan kunyitdaun asam pada minggu ke-6. dapat dilihat pada Tabel 3 .

Tabel 3. menunjukkan bahwa nilai ratarata daya sebar krim antara $5,37 \mathrm{~cm}$ sampai dengan 5,39 cm. Penambahan $\mathrm{pH}$ buffer tidak berpengaruh terhadap daya sebar krim disebabkan karena $\mathrm{pH}$ buffer berfungsi mempertahankan $\mathrm{pH}$ sehingga tidak meningkatkan atau mengurangi daya sebar. Dalam penelitian ini jumlah penambahan emulsifier dan jumlah air pada tiap emulsi sama yang menyebabkan tidak terjadi perbedaan pada daya sebar krim. 
Tabel 3. Nilai rata-rata daya sebar krim ekstrak kunyit, daun asam, dan kunyit-daun asam pada minggu ke-6.

\begin{tabular}{lllll}
\hline \multirow{2}{*}{ Ekstrak } & \multicolumn{4}{c}{$\mathrm{pH}$ Buffer } \\
\cline { 2 - 5 } & 4 & 5 & 6 & Rata-rata \\
\hline Kunyit & 5,39 & 5,39 & 5,39 & $5,39 \mathrm{a}$ \\
Daun asam & 5,38 & 5,38 & 5,38 & 5,38 a \\
Kunyit-daun asam & 5,38 & 5,36 & 5,36 & 5,37 a \\
\hline Rata-rata & 5,38 a & 5,38 a & 5,38 a &
\end{tabular}

Keterangan : huruf yang sama di belakang nilai rata rata menunjukkan perbedaan yang tidak nyata $(\mathrm{P}>0,05)$.

Gambar 2. Grafik daya sebar krim selama 6 minggu penyimpanan.

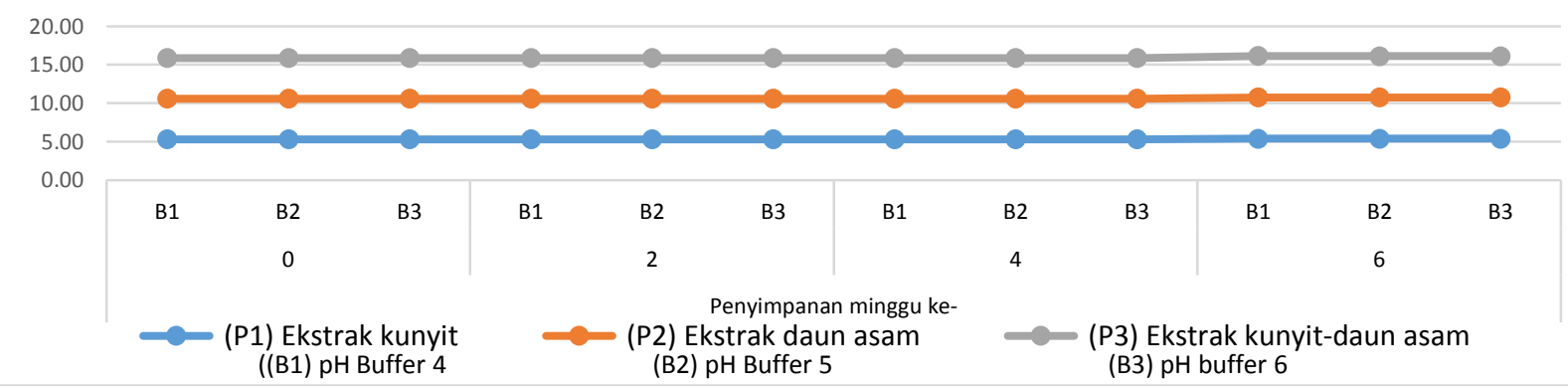

Gambar 2. menunjukkan daya sebar krim pada 6 minggu penyimpanan masih stabil. Menurut Azkiya et al. (2017) emulsi yang stabil disebabkan karena gabungan antara asam stearat dengan trietnolamin, gabungan keduanya memiliki kemampuan untuk mengikat lebih kuat molekul-molekul zat aktif sehingga menambah kestabilan emulsi. Hasil pengamatan menunjukkan bahwa diameter daya sebar krim pada minggu ke-0 sampai minggu ke-6 penyimpanan berkisar antara $5,29-5,39 \mathrm{~cm}$, hal ini menunjukkan daya sebar krim masih berada pada kisaran 5-7 cm sehingga dapat diaplikasikan pada kulit (Rachmalia et al., 2016).

\section{Viskositas krim}

Berdasarkan hasil analisis keragaman pada minggu ke-6 menunjukkan bahwa perlakuan $\mathrm{pH}$ buffer dan penambahan ekstrak tidak berpengaruh nyata $(\mathrm{P}>0,05)$ terhadap vskositas krim. Nilai rata-rata krim krim ekstrak kunyit, daun asam, dan kunyit-daun asam pada minggu ke- 6 dapat dilihat pada Tabel 4.

Tabel 4. Nilai rata - rata viskositas cp (centipoise) krim ekstrak kunyit, daun asam, dan kunyit-daun asam pada minggu ke-6.

\begin{tabular}{lcccc}
\hline \multirow{2}{*}{ Ekstrak } & \multicolumn{3}{c}{ pH buffer } & \multirow{2}{*}{ Rata-rata } \\
\cline { 2 - 4 } & (B1) 4 & (B2) 5 & (B3) 6 & \\
\hline (P1) ekstrak kunyit & 20.200 & 20.400 & 20.200 & $20.267 \mathrm{a}$ \\
(P2) ektrak daun asam & 20.400 & 20.400 & 20.400 & $20.400 \mathrm{a}$ \\
(P3) ekstrak kunyit-daun asam & 20.600 & 20.600 & 20.800 & $20.667 \mathrm{a}$ \\
\hline Rata-rata & $20.400 \mathrm{a}$ & $20.467 \mathrm{a}$ & $20.467 \mathrm{a}$ & \\
\hline
\end{tabular}

Keterangan : huruf yang sama di belakang nilai rata rata menunjukkan perbedaan yang tidak nyata $(\mathrm{P}>0,05)$.

Penambahan $\mathrm{pH}$ buffer dan penambahan ekstrak tidak berpengaruh terhadap viskositas krim, hal ini disebabkan oleh air pada fomulasi jumlahnya sama yang menyebabkan tidak terjadinya perbedaan viskositas pada emulsi krim. Tabel 4. menunjukkan bahwa nilai rata-rata viskositas krim berkisar antara 20.267 cp sampai 
dengan $20.667 \mathrm{cp}$.

Gambar 3. Grafik viskositas krim selama 6 minggu penyimpanan

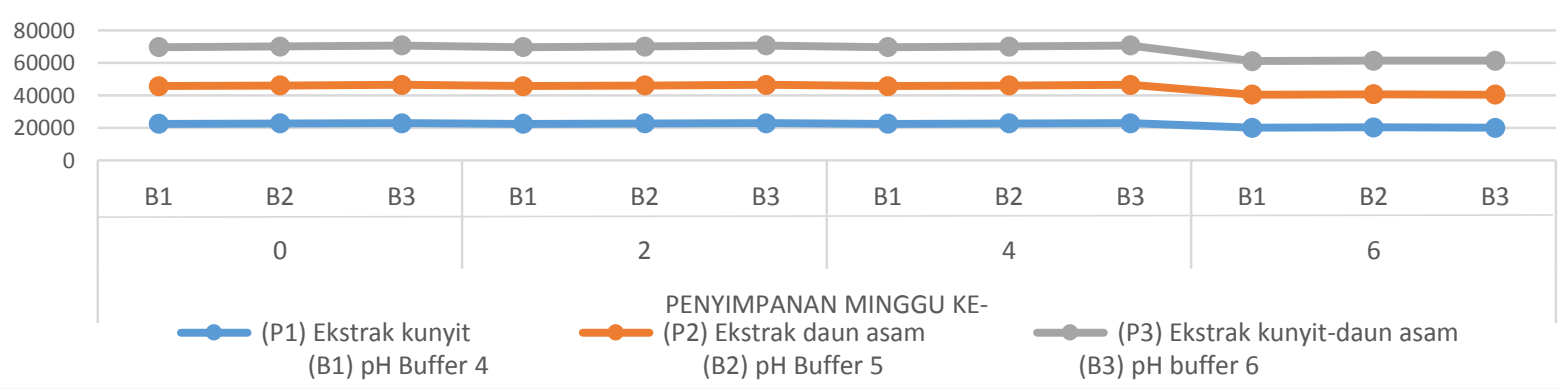

Gambar 3. menunjukkan trend viskositas masih stabil dan tidak terjadi penurunan visositas yang signifikan pada minggu ke-6 penyimpanan. Kestabilan viskositas pada krim karena penggunaan emulsifer berupa trietanolamin, asam stearat dan setil alkohol. Viskositas dalam sediaan emulsi merupakan penghambat dari suatu sediaan untuk mengalir, semakin besar tahanannya maka viskositasnya juga semakin besar. Viskositas suatu sediaan emulsi berpengaruh pada luas penyebarannya. Hasil penelitian menunjukkan viskositas krim pada minggu ke-0 sampai minggu ke-6 penyimpanan berkisar antara $20.200-24.200$ $\mathrm{cp}$, hal ini menunjukkan nilai viskositas sediaan krim masih memenuhi SNI yaitu $2.000-50.000 \mathrm{cp}$ (SNI 16-4399-1996).

\section{Waktu lekat krim}

Berdasarkan analisis keragaman pada minggu ke-6 menunjukkan bahwa perlakuan $\mathrm{pH}$ buffer dan penambahan ekstrak tidak berpengaruh nyata $(\mathrm{P}>0,05)$ terhadap waktu lekat krim. Nilai rata-rata waktu lekat krim krim ekstrak kunyit, daun asam, dan kunyitdaun asam pada minggu ke-6 dapat dilihat pada Tabel 4.

Tabel 4. Nilai rata - rata waktu lekat krim krim ekstrak kunyit, daun asam, dan kunyit-daun asam pada minggu ke-6.

\begin{tabular}{lcccc}
\hline \multirow{2}{*}{\multicolumn{1}{c}{ Ekstrak }} & \multicolumn{3}{c}{ pH buffer } & \multirow{2}{*}{ Rata-rata } \\
\cline { 2 - 4 } & (B1) 4 & (B2) 5 & (B3) 6 & \\
\hline (P1) ekstrak kunyit & 16,90 & 16,86 & 16,85 & $16,87 \mathrm{a}$ \\
(P2) ektrak daun asam & 16,67 & 16,66 & 16,67 & $16,67 \mathrm{a}$ \\
(P3) ekstrak kunyit-daun asam & 16,62 & 16,58 & 16,58 & $16,59 \mathrm{a}$ \\
\hline Rata-rata & $16,73 \mathrm{a}$ & $16,70 \mathrm{a}$ & $16,70 \mathrm{a}$ & \\
\hline Kennnnn
\end{tabular}

Keterangan : huruf yang sama di belakang nilai rata rata menunjukkan perbedaan yang tidak nyata $(\mathrm{P}>0,05)$.

Tabel 4. menunjukkan rata-rata waktu lekat krim pada minggu ke-6 berkisar antara 16,59 detik sampai dengan 16,87 detik. Dalam penelitina ini jumlah emulsifier dan jumlah air yang ditambahkan pada tiap emulsi jumlahnya sama menyebabkan waktu lekat pada tiap emulsi tidak berbeda. Pada emulsi setil alkohol, trietanolamin dan asam stearat berfungsi sebagai emulsifier. Dalam kaitanya dengan waktu lekat emulsifier berbanding terbalik dengan penambahan air.
Jika emulsifier berkurang penambahan airnya lebih banyak dan sebaliknya. Dalam penelitian ini jumlah penambahan emulsifier sama, sehingga waktu lekat tidak berbeda.

Gambar 4. menunjukkan trend waktu lekat krim masih stabil dan tidak terjadi penurunan waktu lekat yang signifikan pada minggu ke-6 penyimpanan. Kondisi ini menunjukkan hubungan yang sejalan dengan viskositas yang dimana pada 6 minggu penyimpanan, viskositas masih stabil. 
Kestabilan waktu lekat pada krim didukung dengan penggunaan emulsifier berupa setil alkohol, asam stearat dan trietanolamin, hal ini disebabkan karena emulsifier bekerja dengan membentuk lapisan disekeliling tetesan terdispersi sehingga mencegah terjadinya pemisahan cairan terdispersi (Anief, 2008). . Hasil pengujian waktu lekat pada minggu ke-0 sampai minggu ke-6 penyimpanan berkisar antara $16,58-22,20$ detik. Menurut penelitian (Rachmalia et al., 2016), waktu lekat yang baik untuk sediaan topikal adalah lebih dari 4 detik, hal ini memungkinkan zat aktif menempel pada permukaan kulit dengan baik.

Gambar 4. Grafik waktu lekat krim selama 6 minggu penyimpanan

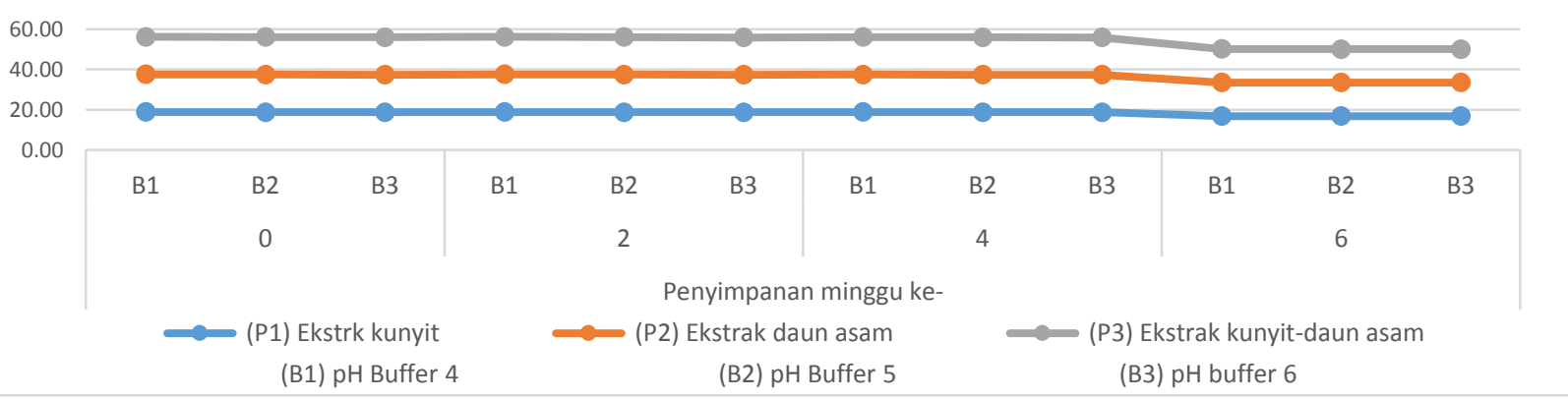

\section{Uji total fenolik krim}

Hasil analisis keragaman menunjukkan bahwa perlakuan $\mathrm{pH}$ buffer tidak berpengaruh nyata $(\mathrm{P}>0,05)$ terhadap total fenolik krim dan penambahan ekstrak berpengaruh sangat nyata $(\mathrm{P}<0,01)$, sedangkan interaksinya tidak berpengaruh nyata $(\mathrm{P}>0,05)$. Nilai rata-rata total fenolik krim pada minggu ke- 6 dapat dilihat pada Tabel 5.

Tabel 5. Nilai rata-rata total fenolik krim ekstrak kunyit, daun asam, dan kunyit-daun asam pada minggu ke-6.

\begin{tabular}{lcccc}
\hline \multirow{2}{*}{ Ekstrak } & \multicolumn{3}{c}{$\mathrm{pH}$ buffer } & \multirow{2}{*}{ Rata-rata } \\
\cline { 2 - 4 } & (B1) 4 & $(\mathrm{~B} 2) 5$ & $(\mathrm{~B} 3) 6$ & \\
\hline (P1) ekstrak kunyit & 10,83 & 10,82 & 10,73 & $10,79 \mathrm{a}$ \\
(P2) ektrak daun asam & 10,09 & 10,04 & 9,93 & $10,02 \mathrm{c}$ \\
(P3) ekstrak kunyit-daun asam & 10,42 & 10,37 & 10,34 & $10,38 \mathrm{~b}$ \\
\hline Rata-rata & $10,45 \mathrm{a}$ & $10,41 \mathrm{a}$ & $10,33 \mathrm{a}$ & \\
\hline
\end{tabular}

Keterangan : huruf yang sama di belakang nilai rata rata menunjukkan perbedaan yang tidak nyata $(\mathrm{P}>0,05)$.

Perlakuan penambahan $\mathrm{pH}$ buffer tidak berpengaruh terhadap fenolik krim dikarenakan $\mathrm{pH}$ buffer hanya berpengaruh terhadap derajat keasaman krim (pH). Dalam penelitian ini krim ekstrak kunyit menghasilkan fenolik tertinggi yaitu sebesar 10,79 mg GAE/g (Tabel 5). Hasil ini sejalan dengan penelitian Riaminanti et al., (2016) yang menyatakan bahwa kandungan total fenolik pada ekstrak kunyit mg GAE/g) lebih tinggi dari ekstrak daun asam $(6,15 \mathrm{mg} \mathrm{GAE} / \mathrm{g})$, hal ini menyebabkan kandungan total fenolik krim ekstrak kunyit tertinggi.

Hasil pengujian menunjukkan senyawa fenol pada minggu ke-0 sampai penyimpanan minggu ke-6 berada pada kisaran 9,93-12,67 mg GAE/g. Gambar 5. menunjukkan trend terjadi penurunan fenol krim pada minggu ke6 penyimpanan. Fenol memiliki sifat yang cenderung asam, sehingga senyawa tersebut cendrung mudah melepas ion $\mathrm{H}^{+}$dari gugus hidroksilnya $(-\mathrm{OH})$. Penurunan kadar total fenolik diakibatkan oleh terjadinya oksidasi 
selama masa penyimpanan (Tristanto et al.,

2017).

Gambar 5. Grafik total fenol krim selama 6 minggu penyimpanan.

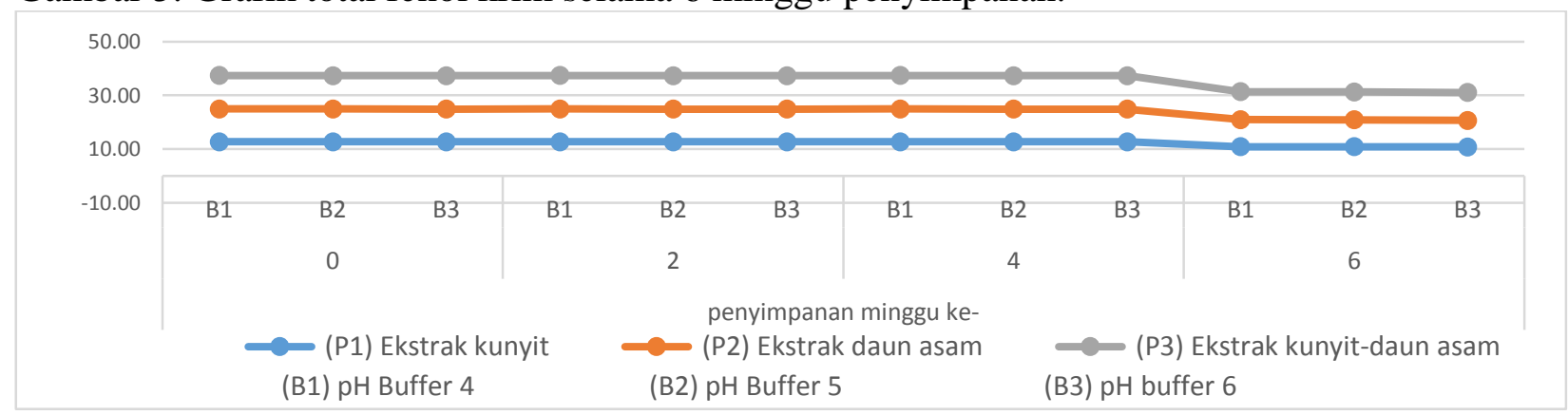

\section{KESIMPULAN DAN SARAN}

\section{Kesimpulan}

Bedasarkan penelitian yang telah dilakukan maka dapat disimpulkan beberapa hal sebagai berikut :

1. Perlakuan penambahan $\mathrm{pH}$ buffer berpengruh terhadap $\mathrm{pH}$ krim, dan tidak berpengaruh terhadap homogenitas, rasio pemisahan, daya sebar, viskositas, waktu lekat, total fenolik krim. Penambahan ekstrak kunyit, ekstrak daun asam, dan kombinasi ekstrak kunyit-daun asam berpengaruh terhadap $\mathrm{pH}$ krim dan total fenolik krim, sedangkan tidak berpengaruh terhadap homogenitas, rasio pemisahan, daya sebar, viskositas, waktu lekat krim. Larutan $\mathrm{pH}$ buffer mampu mempertahankan $\mathrm{pH}$ krim, penambahan daun asam mengakibatkan penurunan $\mathrm{pH}$ krim. Senyawa fenolik tertinggi dihasilkan pada penambahan ekstrak kunyit.

2. Semua formulasi krim memenuhui SNI yaitu karakteristik krim homogen, rasio pemisahan $=1, \mathrm{pH}$, daya sebar, viskositas, waktu lekat, dan total fenolik, dengan formulasi terbaik pada pH Buffer 4 dan ekstrak kunyit yaitu pH krim $(6,68)$, daya sebar krim $(5,39)$ cm, viskositas krim $(20,200) \mathrm{cp}$, waktu lekat krim $(16,90)$ detik, dan total fenolik krim $(10,83) \mathrm{mg}$ GAE/g.

\section{Saran}

Perlu dilakukan penelitian lebih lanjut tentang penambahan bahan aktif lainya pada krim dan bahan pengemulsi yang digunakan yang mampu menghasilkan krim dengan karakteristik krim yang lebih baik.

\section{DAFTAR PUSTAKA}

Anief, M. 1999. Sistem Dispersi, Formulasi Suspensi dan Emulsi. Gadjah Mada University Press, Yogyakarta.

Anief, M. 2008. Ilmu Menarik Obat. Gadjah Mada University Press, Yogyakarta.

Badan Standarisasi Nasional. 1996. Sediaan Tabir Surya. Standar Nasional Indonesia. Jakarta.

Herawati, S, 2008. Kajian Materi Larutan Buffer Asam-Basa. Tesis S2. Tidak dipublikasi. ITB, Bandung.

Hidayat, M., S. Soeng, S., Prahastuti, T.H. Patriciadan, K.A. Yonathan. 2014. Aktivitas Antioksidan dan Anti trigleserida Ekstrak Tunggal Kedelai, Daun Jati Belanda Serta Kombinasinya. Jurnal Ilmu Hayati, 16(2) : 89-94.

Kurniasih, N. 2016. Formulasi Sediaan Krim 
Tipe M/A Ekstrak Biji Kedelai (Glycine $\max$ L) : Uji Stabilitas Fisik dan Efek Pada Kulit. Fakultas Farmasi. Universitas Muhammadiyah. Surakarta. http://www.esprints.ums.ac.id. Diakses pada tanggal : 15 april 2018.

Mulyani, S., K. Satriawan L. Triani, IGA. 2006. Potensi Minuman Kunyit Asam (Curcuma domestica Val Tamarindus indica L.) Sebagai Sumber Antioksidan Beserta Analisis Finansialnya, Laporan Research Grant, TPSDP. ADB- LOAN.

Mulyani, S and Suhendra, L. 2010. Tamarind Leaf Extraction (Tamarindus indica L.) Ethanol-Dextrin Encapsulation: Study of Antioxidant. Proceding $2^{\text {nd }}$ International Conference on Bioscience and Biotechnology. "Pave the Way to A Better Life".

Mulyani, S. 2017. Sinergisme Antioksidan Kunyit Dan Daun Asam (Curcuma domestica Val. - Tamarindus indica L.) Sebagai Bahan Aktif Krim. Disertasi. Program Program Studi Doktor (S3) Ilmu Pertanian Fakultas Pertanian Universitas Udayana. Denpasar.

Natalie, A., S. Mulyani and B, Admadi, H. 2017. Hubungan Lama Simpan Dengan Karakteristik Mutu Pada Beberapa Formulasi Krim Ekstrak Kunyit (Curcuma domestica Val.). Jurnal Rekaya dan Manajemen Agroindustri. 5(4) : 21-30.

Priyadarsini, K.I., D.K. Maity, G.H. Naik, M.S. Kumar, M.K. Unnikrishnan, J.G. Satav, and H. Mohan. 2003. Role Of Phenolic O-H and Methylene Hydrogen On The Free Radical Reactions and Antioxidant Activity Of Curcumin. Free Radic Biol Med. $35(5): 84-475$.
Purba, E. R and Martosupono, M. 2009. Kukumin Sebagai Senyawa Antioksidan. Jurusan Biologi, Universitas Kristen Satya Wacana Salatiga, Jawa Tengah.

Rachmalia, N., I., Mukhlishah, N., Sugihartini, T., Yuwono 2016. Daya iritasi dan sifat fisik sediaan salep minyak atsiribunga cengkeh (Syzigium aromaticum) Pada Baasis Hidrokarbon. Farmaseutik. (12) : 372-376.

Riaminanti, N.K., A.,Hartiati., S., Mulyani. 2016. Studi Kapasitas dan Sinergisme Antioksidan Pada Ekstrak Kunyit (Curcuma domestica Val.) dan Daun Asam (Tamarindus indicia L.). Jurnal Rekayasa dan Manajemen Agroidustri. 4(3) : 93-104

Singh, M., Sharma, S., Khokra, S. L., Sahu, R. K., and Jangde, R., 2011, Preparation and Evaluation of Herbal Cosmetic Cream, India, pp 1258 1264.

Thamrin, N.F. 2012. Formulasi Sediaan Krim Dari Ekstrak Etanol Kunyit (Curcuma domestica. Val) dan Uji Efektivitas Terhadap Bhakteri Sthaphylococcus Aureus. Tidak dipublikasi. Fakultas Ilmu Kesehatan, Univeritas Islam Negeri Alaudin, Makasar.

Tranggono, R.I., F. Latifah. 2007. Buku Pegangan Ilmu Pengetahuan Kosmetik. PT. Gramedia, Jakarta.

Tristanto, N.A., T.D.W., Budianta., A.R., Utomo. 2017. Pengaruh Suhu Penyimpanan dan Proporsi Teh Hijau : Bubuk Daun Kering Stevia (Stevia rebaudiana) Terhadap Aktivitas Akntioksidan Minuman Teh Hijau Stevia Dalam Kemasan Botol Plastik. Jurnal Teknologi Pangan dan Gizi. Vol 10 : 79-87. 
Yumas, M. 2016. Formulasi Sedian Krim

Wajah Berbahan Aktif Ekstrak

Metanol Biji Kakao Non Fermentasi

(Theobromo cacao L.). Kombinasi

Madu Lebah. Balai Besar Industri

Hasil Perkebunan, Makasar. 